\title{
Patterns of Islamic Education Learning in Applying 2013 Curriculum in SMPN 27 Medan
}

\author{
Ali Imran Sinaga ${ }^{1}$, Salamuddin ${ }^{2}$, Dewi Khairini ${ }^{3}$ \\ ${ }^{1,2,3}$ Faculty of Tarbiyah and Teacher Training, Universitas Islam Negeri Sumatera Utara, Indonesia \\ dewikhairini51@gmail.com
}

\begin{abstract}
The research objectives were to find out: (1) how teachers implement Islamic religious education learning in the 2013 curriculum, (2) steps in applying the 2013 curriculum, and (3) problems related to the pattern of Islamic religious education in implementing the 2013 curriculum. The research method used is qualitative research, data collection is carried out in natural conditions and using data collection methods, namely: interview method, observation method, documentation method. Activities in data analysis are: data reduction, data presentation, and drawing conclusions. The research findings show: (1) the teacher first makes a Learning Implementation Plan by paying attention to the aspects of the life skills developed, the media used and the assessments carried out, (2) the learning process is carried out by applying a scientific approach, as well as active learning strategies, including modeling the way, reading aloud, reading guide, group resume, and (3) evaluations conducted by the teacher using an authentic assessment system which includes cognitive aspects, skills aspects, and affective aspects (spiritual and social).
\end{abstract}

Keywords

islamic education; curriculum; scientific approach; competencies

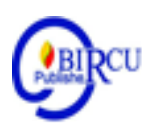

\section{Introduction}

The pattern of Islamic education is a method taken by teachers in educating children as an embodiment of and a sense of responsibility towards children. A good way of educating in family and society is expected to be able to develop children's personalities into strong personalities and have positive attitudes and quality intellectuals. By providing material, children are expected to be pious, Muslim and kamil personalities, all of which want people who serve Allah SWT. Sincerely, so that his soul, attitude, interests, life philosophy and beliefs show devotion and self-knowledge to Allah. The pattern of Islamic religious education is the way and attitudes of parents in leading children who are shown with an authoritarian, liberal, or democratic attitude that can affect the development and characteristics of certain individual characteristics.

The implication of the learning objectives of Islamic education in schools that is the main focus is the problem of morals. Islamic religious education teachers often receive reprimands and become targets if there are students who are not good. This is a whip and at the same time a challenge for Islamic religious teachers, even though this should be a shared responsibility for all teachers and school members. However, this fact is not an easy problem, as easy as turning the palm of the hand, but it requires a mental and spiritual calling in living it, because a teacher must find many challenges in carrying out this noble task. 


\section{Review of Literatures}

Islamic education is the whole of the teachings of Islam brought by the Prophet Muhammad which includes man's relationship with God, with fellow humans, with himself, and with the natural surroundings. In the translation includes faith, sharia, and morals. (Namsa, 2000: 23). Furthermore, Syafaruddin (2006: 54) explains that education is defined as a business run by a group of other people to become adults. The ideology of education is used in order to encourage a more dynamic educational movement in community empowerment, so it is not just a philosophy with a very abstract aroma of knowledge. However, to accept the truth is not a belief like religion.

Furthermore, Muhaimin (2003: 56) explains that a teacher of Islamic Education must be able to bear the burden and all the risks as a consequence. Therefore, teachers must educate their students with full sincerity and ask for His help so that they are given convenience in fostering and shaping students to become believers and fear Allah SWT. Learning is the actualization of the curriculum that requires teacher activeness in creating and growing the activities of students in accordance with the programmed plan. The teacher must master the principles of learning, choose and use learning media, the ability to assess the learning outcomes of the participants in the study, and choose and use learning strategies or approaches (Mulyasa 2011:117). According to (Uzer Usman 2010: 34) the learning process is a process that contains a series of actions of teachers and students on the basis of reciprocal relationships that take place in an educational situation to achieve certain goals. Learning is essentially a process of interaction between students and their environment, so that there is a better change in behavior. Learning is an integral (whole integrated) and intentional activity between students and teachers to achieve goals that have been formulated, namely the existence of changes in behavior including knowledge, experience, skills, and characters so on. (Kunandar 2013) said that "learning is the process of interaction between students and their environment so that behavior changes occur towards a better direction". In learning the most important task is to identify the environment in order to support the occurrence of behavior for students. Whereas (Dimyati \& Mudjiono 2013) "Learning is a process organized by teachers to teach students to learn and process knowledge, skills and attitudes."

The curriculum is a tool to achieve educational goals without an appropriate and appropriate curriculum it will be difficult to achieve the desired educational goals and objectives as an important tool to achieve goals. The curriculum should be adaptive to changing times and advances in science and technological sophistication. The curriculum develops in line with developments in educational theory and practice. The curriculum must be able to provide direction and benchmark of expertise to students after completing a teaching program at an institution. The curriculum is always changing and developing in accordance with the progress of the times, science and technology that are happening. (Sukmadinata, 2002: 4).

The curriculum is the foundation used by education to guide the desired students through the accumulation of a number of knowledge, skills and mental attitudes. (AIRasyidin, 2005: 56). Meanwhile, according to Syafruddin and Nurdin (2006: 34) that the curriculum is any activity carried out by schools in order to influence children in learning to achieve a goal, it can be called a curriculum including teaching and learning activities, arranging strategies in the teaching and learning process, how to evaluate teaching development programs, and so on.

The 2013 curriculum is a curriculum based on competencies, the development of the 2013 curriculum is directed at achieving competencies formulated in graduate competency 
standards (SKL). The preparation of the 2013 curriculum began by setting graduate competency standards based on student preparation and national education goals. The 2013 curriculum is set to be the first education delivery tool in the 2013/2014 school year for the number of target schools. (Martiyono, et al, 2014: 38).

Daryanto (2014: 51) explains learning with a scientific approach is a learning process designed in such a way that students actively construct concepts, laws or principles through stages of observing (to identify or find problems), formulate problems, propose or formulate hypotheses, collecting data with various techniques, analyzing data, drawing conclusions and communicating the concepts, laws or principles found. In learning, students are encouraged to discover for themselves and transform complex information, check new information with what is already in their memories and develop into information or abilities that are appropriate to the environment, era, place, and time they lived.

The scientific approach is an approach in learning activities that prioritizes students' creativity and findings. According to Kosasih (2014: 72) the characteristics of scientific learning are as follows: (1) Learning material is understood with logical standards that are appropriate to the level of maturity, but it is also possible for students to criticize, know the acquisition procedure, even their weaknesses, (2) learning interactions take place openly and objectively. Students have the broadest opportunity to express their thoughts, feelings, attitudes, and experiences. But students still pay attention to scientific attitudes and responsibilities, and (3) Students are encouraged to always think analytically and critically. Accurately in understanding, identifying, solving problems, and applying learning materials. The scientific approach is very focused on students in the learning process. The cognitive process of students will develop because students are directly involved in learning both in the classroom and outside the classroom.

Scientific approach is also called the scientific approach. This is in line with the implementation of the 2013 curriculum, which is required by the government. The approach that must be applied in schools is to apply the 2013 curriculum. This is in accordance with Permendikbud number 20 of 2016 concerning the Basic and Secondary Education Process Standards which has hinted at the need for a guided learning process with the principles of scientific/ scientific approach (Regulation of the Minister of Education and Culture of the Republic of Indonesia Number 20 concerning Basic and Secondary Education Process Standards, 2016: 1).

\section{Research Method}

The research method used is qualitative research, data collection is carried out in natural conditions and using data collection methods, namely: interview method, observation method, documentation method. In accordance with the main problems of this study, the types, characteristics, and sources of research carried out, the data collection chosen for further analysis in depth is the method of observation, interviews, and documentation. Sources of data in this study include primary data sources and secondary data sources. Activities in data analysis are: data reduction, data presentation, and drawing conclusions.

\section{Discussion}

The development of annual programs, semester programs, weekly and daily programs prepared by Islamic Education teachers at SMPN 27 Medan have been compiled according to the 2013 curriculum references. The teachers compile them together in a team. Usually the 
program is structured at the beginning of the school year. Each teacher has their respective duties, so that the preparation does not experience significant obstacles

In the principle of developing a 2013 curriculum-based syllabus, each education unit is given freedom and flexibility in developing a syllabus according to the conditions and needs of each school. This principle has been implemented by the Islamic Education teacher at SMPN 27 Medan in developing the syllabus. In developing the syllabus into a Learning Implementation Plan that is in accordance with the 2013 curriculum references, the following steps need to be taken: (1) reviewing core competencies and basic competencies, (2) identifying the main material, (3) developing learning experiences, (4) formulating indicators of learning success, (5) determining the type of assessment, (6) determining the allocation of time.

In general, in syllabus development, Islamic Education teachers did not experience significant obstacles, because the teachers in the preparation of the syllabus were carried out jointly in a team, namely in the school-level Subject Teacher Conference. Likewise in the preparation of a learning implementation plan that is in accordance with the 2013 curriculum references. In general, the teacher does not experience difficulties in compiling the lesson plan, because the teacher has received a reference or guideline in the preparation of the learning implementation plan. In preparing lesson plans, teachers are given the freedom to develop a syllabus that is adapted to school conditions, the media, and the characteristics of students.

The implementation of the curriculum must be seen from the situation and condition of the school which encourages all elements to play an active role in educating and providing character education for students who are accountable and behave in accordance with educational goals. The implementation of a new system certainly contains various supporting factors so that success can be achieved optimally. From the results of the description and data analysis, it can be concluded that the supporting factors in the implementation of the 2013 curriculum on Islamic Education learning at SMPN 27 Medan include: (1) The learning infrastructure at SMPN 27 Medan, quantitatively and qualitatively, is sufficient. These infrastructure facilities such as the availability of internet facilities, computer laboratories, LCD, laptops, pictures, a complete library, besides that, the construction of supporting buildings is also being carried out. (2) The existence of school programs in the context of implementing the 2013 curriculum, among others: (a) Socializing the concepts of the 2013 curriculum by involving student guardians at the beginning of semesters 1 and 2. (b) The formation of the 2013 curriculum committee, this involves stakeholders including school principals, teachers, counselors, school committees. . (c) The existence of a team of 2013 curriculum developers and compilers that involved each teacher of certain subjects. (d). Once a month, an evaluation is carried out which is packaged in a school official meeting.

In implementing the 2013 curriculum, there will be a number of problems in the field besides paradigmatic problems, such as changing the teacher's mindset, there are also technical problems related to changes in curriculum structure. From the results of the description and data analysis, it can be concluded that the inhibiting factor in implementing the 2013 curriculum on Islamic Education learning at SMPN 27 Medan is that in the 2013 curriculum teachers are required to implement an authentic assessment system, but in practice Islamic Education teachers have not been able to meet these demands because in this curriculum attitude assessment is the first and foremost, then followed by an assessment of skills and knowledge.

The factors that become obstacles in the assessment process include differences in the characteristics of each student, so that the teacher finds it difficult to identify or memorize one by one these students. When learning takes place, the teacher must assess the four aspects 
of competence by assessing all indicators for each student so that the teacher feels overwhelmed because at that time the teacher has to guide students in learning. In the 2013 curriculum, it is required to use varied and fun learning methods such as: inquiry, discovery, contextual, problem solving and so on.

In the learning process in the 2013 curriculum using a scientific approach that goes through several steps, namely observing, asking, gathering information, associating and communicating. However, in practice the teacher has difficulty in sorting learning activities into five stages of the scientific approach and other serious obstacles such as limited time, energy and abilities, so that the use of methods and application of approaches in learning has not been optimal. Many students, especially grade VII students, are not ready to be independent in learning, this is because students are still used to the conventional system that was brought from school at the previous level, and students are always passive in learning. This is clearly very different from the 2013 Curriculum, currently students are central in the learning process, while the teacher is only a facilitator in creating a pleasant and meaningful classroom atmosphere.

The efforts made by schools and teachers of Islamic Education in facing the obstacles that occur in the implementation of the 2013 curriculum. In implementing the 2013 curriculum which is still in a new stage, of course there are still difficulties faced by teachers as the main actors in implementing the curriculum. In fact, due to differences in teacher skills and knowledge, not all teachers have been able to develop learning activities that can facilitate students to observe phenomena that occur related to their subject matter.

The solutions made by schools and teachers of Islamic Education are as follows: (1) strengthening the scientific approach to teachers through subject teacher deliberations, (2) teachers getting continuous training so that they are adept at implementing the steps of the scientific approach, (3) adjusting the material or theme lessons with the method and steps of the approach taken, (4) assessment through classification according to student abilities (5) the school provides intensive guidance for new students through student council programs or extracurricular activities, (6) holds outreach to guardians of students at the beginning school year, and (7) schools improve learning facilities and media.

\section{Conclusion}

The conclusions that can be drawn are: (1) before carrying out learning, the teacher first makes a learning implementation plan by paying attention to the aspects of the life skills being developed, the media used and the assessments carried out. However, there are some things that are less than optimal, namely identifying needs, analyzing learning, and identifying students' initial behavior and characteristics, (2) the learning process is carried out by applying a scientific approach, as well as active learning strategies, including in the form of modeling the way, reading aloud, reading guide, group resumes, and (3) evaluations conducted by the teacher using an authentic assessment system, which includes cognitive, skill, and affective (spiritual and social) aspects.

Suggestions that can be given are: (1) to school leaders to further improve the quality of learning by providing opportunities for teachers to participate in training related to learning strategies, learning designs, use of ICT-based media, and also completing learning infrastructure such as equipping libraries with books more religious books and procurement of religious practice laboratories, and (3) teachers are advised to develop the application of active learning strategies and use ICT-based media. 


\section{References}

Al-Rasyidin dan Nizar. Kurikulum dan Pembelajaran Pendidikan Agama Islam. Jakarta: Aksara, 2005.

Ayuningsih, W., Syafaruddin, M.S Amiruddin. (2020). Implementation of Islamic Education Curriculum Development in Al-Ulum Islamic School Medan. Budapest International Research and Critics in Linguistics and Education (BirLE) Journal Vol 3 (2): 10331044.

Budianti, R., Mardianto, Zulheddi. (2020). Implementation of Tikrar Methods in Memorizing Al-Qur'an in Tahfidzul Qur'an Foundation Al-Fawwaz Medan. Budapest International

Research and Critics in Linguistics and Education (BirLE) Journal Vol 3 (2): 974-980.

Daryanto. 2014. Pendekatan Pembelajaran Saintifik. Yogyakarta: Gava Media.

Dimyati \& Mudjiono. 2013. Belajar Dan Pembelajaran. ed. Rineka Cipta. Jakarta.

Kosasih, E. 2014. Strategi Belajar dan Pembelajaran Implementasi Kurikulum 2013. Bandung: Yrama Widya.

Kunandar. 2013. Penilaian Autentik (Penilaian Hasil Belajar Peserta Didik Berdasarkan Kurikulum 2013). Jakarta: Raja Grafindo Persada.

Muhaimin, Wacana Pengembangan Pendidikan Islam, Yogyakarta: Pustaka Pelajar, 2003.

Mulyasa, E. (2013). Pengembangan dan Implementasi Kurikulum 2013, Bandung: PT Remaja Rosdakarya 2013.

Mulyasa, E. 2011. Standar Kompetensi Dan Sertifikasi Guru. Bandung: Remaja Rosdakarya. Nana Syaodih Sukmadinata, Kurikulum dan Pembelajaran, Bandung: Karya Kesuma, 2002.

Nasution, N., and Rafida, T. (2019). The Effect of Stress Control and Expectation on Satisfaction with Teacher Colleagues in MTsN (Islamic Junior High School) Stabat, Langkat Regency, Indonesia. Budapest International Research and Critics in Linguistics and Education (BirLE) Journal Vol 2 (2): 66-80.

Noie, S. (2018). An Investigation of Mystic Term on "Conference of The Birds" of Attar on The Basis of Van Doorslaer's Map. Budapest International Research and Critics in Linguistics and Education (BirLE) Journal Vol I (1): 1-10.

Rahmati, M. (2019). The Effect of Task-Based Syllabus on Iranian EFL Learners. Budapest International Research and Critics in Linguistics and Education (BirLE) Journal Vol 2 (4):32-43.

Rusydi Ananda, Perencanaan Pembelajaran. Medan: LPPPI, 2019.

Siahaan, A., Hafsah, and Mandala, S. (2020). The Effect of Scientific Approach and Interpersonal Interaction of Islamic Education to Student Characters in Integrated Islamic School Al Hafiz Langkat District. Budapest International Research and Critics in Linguistic s and Education (BirLE) Journal Vol 3 (3): 1281-1286.

Siregar, S.F., Mardianto, and Ahkas, A.W. (2020). Extracurricular Implementation of Islamic Education in Character Building Students in MTs EX PGA UNIVA Medan. Budapest International Research and Critics in Linguistics and Education (BirLE) Journal Vol 3 (2): 965-973.

Syafaruddin dan Nurdin, Implementasi Kurikulum, Jakarta : Ciputat Pers 2006

Syafaruddin, Ilmu Pendidikan Islam, cet ke 1 Jakarta Selatan : Ciputat, 2006

Uzer Usman, Moh. 2010. Menjadi Guru Profesional. Bandung: Remaja Rosdakarya.

Wardany, D.K. (2019). The Effect of Islamic Education Subject on the Development of Student Social Behavior. Budapest International Research and Critics in Linguistics and Education (BirLE) Journal Vol 2, (2): 92-99.

Yunus Namsa, Metode Pengajaran Agama Islam, Ternate :Pustaka Firdaus 2000. 